Mark A. Graber

\title{
CONSTITUTIONAL THEORY GOES TO MARKET
}

The state of constitutional theory is usually assessed from the perspective of a particular constitutional theory. The conclusion typically is that constitutional theorists should be paying more attention to what the author is doing and less attention to matters the author has either abandoned or ignored. Scholars who study constitutionalism outside of the courts complain that constitutional theorists spend too much time telling Supreme Court justices how to do their job and too little time critiquing the constitutional performance of other political actors. ${ }^{1}$ Devotees of law and economics insist that constitutional theory would be improved by more and better use

\footnotetext{
${ }^{1}$ See Mark Tushnet, Taking the Constitution Away from the Courts (Princeton
} University Press: Princeton, New Jersey, 1999), p. 155. 
of rational choice. ${ }^{2}$

This essay assesses the state of constitutional theory from the perspective of higher education and academic freedom. Constitutional theory in the contemporary United States is largely yoked to the fate of the academy. Studies on the nature and improvement of political orders are produced and disseminated largely in universities, colleges and university presses. When these institutions are flourishing, constitutional theory is likely to be flourishing. Constitutional theory is healthy, no matter what the particular scholarly fashions at any time, when academic environments are created and maintained in which constitutional theory is a valued enterprise and constitutional theorists are free to explore those aspects of that enterprise thought worthwhile. Themes and ideas compete for intellectual attention based on how attractive they appear to numerous persons who think contemplating questions of political design an important endeavor. Until the human intellect is perfected, misjudgments, mistaken priorities and bias will occur even in ideal speech situations. Nevertheless, when constitutional theory is valued and free, the products of such contemplating are likely to be as good in that time and place as is humanely possible.

${ }^{2}$ See generally, Lee Epstein and Gary King, AEmpirical Scholarship and the Goals of Legal Scholarship,@ 69 University of Chicago Law Review 1 (2002) (calling on law professors to adopt methods used by behaviorists in political science). 
Most commentary on academic freedom focuses on the concern that constitutional theory and related inquiries are not free, rather than on the concern that constitutional theory and related inquiries are not valued. Proponents of academic freedom are ever alert to combat pressures that may dissuade scholars in all disciplines from relying on those methods or reaching those conclusions they think best. These threats to the academic and constitutional enterprise, however, are often rooted in strong commitments to the value of academic and constitutional discourse. The greater threat to higher education and constitutional theory during the twentiethfirst century is a decline in these commitments. Academic values associated with truth seeking are increasingly being subordinated to external norms associated with the university=s quest for more funding. As higher education goes to market, the result is likely to be less constitutional theory and less interesting constitutional theory.

\section{A. Censorship, Academic Freedom, and Constitutional Theory}

The traditional threat to higher education and constitutional theory is pressure for conformity. Lines of inquiry that seem intellectually attractive are abandoned or not adequately pursued because persons who control academic life do not tolerate serious challenges to reigning political or scholarly orthodoxies. Constitutional and other thinkers during the 1950 s too closely identified with communism or socialism risked losing their positions. ${ }^{3}$ Many conservatives complain that the academy is presently biased against constitutional thinkers who defend free

${ }^{3}$ See Ellen W. Schrecker, No Ivory Tower@ McCarthyism and the Universities (Oxford University Press: New York, 1986). 
markets and Atraditional@ values. ${ }^{4}$ Particular reviewers, departments, and disciplines are not open to any scholarship that does not rely on statistics, makes too much use of formal theory, or concludes that big business supported Hitler. ${ }^{5}$ Constitutional theory shaped by these and related pressures devolves into an exercise in discovering additional proofs for what is already known and providing additional reasons for what is already believed.

${ }^{4}$ The best known work in this genre is Roger Kimball, Tenured Radicals: How Politics Has Corrupted Our Higher Education (revised edition) (Ivan R. Dee, Inc.: New York, 1998).

${ }^{5}$ On the latter, see Peter Novick, That Noble Dream: The AObjectivity Question@ and the American Historical Profession (Cambridge University Press: New York, 1988), p. 
Pressures for conformity are difficult to evaluate in political or university settings when they are plausibly linked to substantive commitments underlying the policy or the academy. Just as atheists are justly denied admission to seminaries and the German constitution bans parties committed to undermining certain democratic norms, so arguably might a communist who rejects academic freedom be denied teaching positions. ${ }^{6}$ Universities are committed to norms of civility and quality. Professors should fail a paper that does no more than rant, even if such speech is protected by the First Amendment. Proponents of discrimination against homosexuals are not entitled to representation on faculties simply because many persons hold such beliefs, if no respectable justification exists for such policies. ${ }^{7}$

These examples illustrate how the difference between censorship and upholding legitimate academic standards often depends on contestable notions of constitutionalism and academic freedom. When constitutional theorists compete for scarce publication spaces and faculty positions, some standard must be used for distinguishing better scholarship from worse. Senior academics who cannot agree on the best constitutional theories are likely to dispute what works in constitutional theory are sufficiently scholarly to merit publication or inclusion on a syllabus. The gatekeepers for constitutional theory will not only often be misguided, they will sometimes be insincere. Nevertheless, if hypocrisy is the tribute vice pays to virtue, one important limit on traditional threats to constitutional theory and academic freedom is that exclusion must be justified in terms of values internal to constitutionalism and higher education.

\footnotetext{
${ }^{6}$ For a fascinating discussion of these and related questions, see Sanford Levinson, Constitutional Faith (Princeton University Press: Princeton, New Jersey, 1988), pp. 155-79.

${ }^{7}$ See Stephen Macedo, AHomosexuality and the Conservative Mind,@ 84 Georgetown Law Journal 261 (1995).
} 
One must make plausible claims that an argument is incompetent or subversive before denying the author an academic position or audience.

\section{B. Money, Academic Integrity and Constitutional Theory}

Contemporary threats to constitutional theory are increasing associated with external challenges to the value of the academic enterprise, rather than disputes over the implementation of academic values. The traditional virtues of teaching and research are being discarded or demphasized as the university turns to the marketplace for more money. The concern for financing, standing alone, is not new. Economic realities have always required some compromises with academic norms. Witness the role of big time athletics, whose role seems limited to fundraising, publicity, and embarrassing the faculty. What has changed is the intensity of financial concerns and the increased prominence of market considerations in academic decision-making. Some reasons are external to the university. At a time when the normal costs of academic life are increasing, local legislatures are reducing university budgets and federal largess has been cut. ${ }^{8}$ Other reasons are internal. Partly as a consequence of the need for new sources of revenue, university administration is increasingly being turned over to persons whose values are shaped by the marketplace rather than by any intellectual commitments. The New York Times reports that university presidents are now expected to be Asmooth fundraisers,@ not

${ }^{8}$ See Ellen W. Schrecker, AFree Speech on Campus: Academic Freedom and the Corporations,@ The Boundaries of Freedom of Expression \& Order in American Democracy (Kent State University Press: Kent, Ohio, 2001), pp. 233-38. Much of the material in the this and the next paragraph are taken from Professor Schrecker=s important essay. 
Aoutspoken ... and a public figure.@ $\bigcup^{9}$ Deans and associate deans share these priorities.

${ }^{9}$ Kate Zernicke and Pam Belluck, AHarvard President Brings Elbows to the Table,@ New York Times, January 6, 2002, p. 20. 
Money becomes the measure of all things academic as the university goes to market. Administrators justify greater funding for higher education by emphasizing how research improves material standards of living. In the words of one academic bureaucrat, universities advance Aeconomic development by developing knowledge-linked activities that enhance technological commercialization, support organizational and community change, and enhance the competencies of workers and professionals.@ ${ }^{10}$ Research is oriented toward obtaining private sector funding. Dollars replace citation counts as the objective measure of scholarly productivity. The quality of ideas often seems moot. Some universities encourage faculty to sign and honor agreements not to publish adverse findings when doing so facilitates obtaining a large grant. Undergraduate education is a credentialing service aimed at increasing student income upon graduation. Students are consumers who are to be satisfied rather than citizens who are to be educated.

Exaggerating the influence of money is easily done in a polemic. Many areas of university life, most notably junior hires and promotion, remain largely untouched by the entrepreneurial imperative. Well funded law schools (and elite private universities) are less affected by market concerns than public undergraduate and $\mathrm{PhD}$ granting programs. Nevertheless, market norms have become far more prominent when academic decisions are made. Administrators spend more time determining whether Pepsi or Coke shall have exclusive marketing rights on campus. Less energy is spent defending the public value of universities, university research and university education. These trends are not limited to the academy. At a time when the Supreme Court majority is increasingly equating commercial speech and public

${ }^{10}$ Schrecker, AFree Speech on Campus,@ p. 239. 
discourse, ${ }^{11}$ we should not be surprised that universities are equating consumers and citizens, and that higher education is regarded as just another business or interest group.

\section{Constitutional Theory in the New University}

Constitutional theorists have particular reasons for concern about the market-driven university. Markets are likely to be bad for constitutional theorists, bad for the production of constitutional theory and bad for the dissemination of constitutional theory. The increased sense that money is the measure of all things academic is likely to further foster a sense that money is the measure of all things political, indeed of all things. Notions that the good life may not be a life devoted to money making or that the good polity may have goals other than immediate wealth maximization are likely to seem absurd in the present university climate. To the extent constitutional theorists enthusiastically participate in the quest for funding, citizens, legislators and students are likely to perceive with some reason that the primary purpose of constitutional theory is to provide resources for constitutional theorists.

${ }^{11}$ See especially, Lorillard Tobacco Co. v. Reilly, 533 U.S. 525, 575 (2001) (Thomas, J., concurring). 
A market driven university is bad for constitutional theorists, who are unlikely as a group to win the enormous grants cherished by the contemporary academy. Constitutional research is largely a solitary enterprise. What is needed is time to read, reflect, and discuss. Few constitutional theorists need teams of research assistants and even fewer need equipment more complicated that a computer that can handle basic word processing. Creative constitutional theorists will think of ways to expand budgets, but their efforts will easily be dwarfed by other scholars whose research really does require substantial funding. Unable to compete entrepreneurally, constitutional theorists will be poorly placed to obtain new positions or even maintain existing lines. Recent developments in public law may be a harbinger of a more general future. At a time when a renaissance is taking place in constitutional theory among political scientists, ${ }^{12}$ positions are being taken away. Publications in the leading scholarly journals and university presses have not inspired university administrators to retail existing slots for scholars who do not get research grants. As the supply of constitutional theorists diminishes, so will constitutional theory.

A market driven academy produces bad constitutional theory. Grant funding is problematic even in the hard sciences. Corporations fund only research likely to improve their market share. Problems associated with bias are greater in constitutional theory. Most outside groups who fund constitutional theory projects or constitutional theorists are primarily interesting in generating justifications for their preferred policies. New ideas flourish in this environment only when powerful groups outside the academy have interested reasons for

${ }^{12}$ See, i.e., Mark A. Graber, AConstitutionalism and Political Science: Imaginative Scholarship, Unimaginative Teaching,@ [should be forthcoming from Perspectives on Politics by the time this is copyeditedBif not I=ll substitute another cite] 
promoting those ideas. The libertarian turn in constitutional scholarship, for example, is partly a consequence of the increased resources available to libertarian constitutionalists. Funding on the left promises similar untoward consequences. When constitutional theorists must obtain outside support, constitutional theory is likely to become more reliable across the board. Theorists on both the left and right will devote energy to finding new reasons for supporting existing clusters of political positions, rather than offering truly new ways of conceptualizing the constitutional universe.

Grant funding skews constitutional theory in unfortunate ways even when not explicitly concerned with politically correct conclusions. Constitutional theorists may be tempted to employ politically correct quantitative methods when exploring political regimes in order to obtain prestigious grants from the National Science Foundation. A good case can be made that the increased sovereignty of rational choice and statistical research in political science has far more to do with the availability of funding than the comparative merits of behavioral and humanistic research. Intellectual entrepreneurs tend to practice celebrity constitutional theory, which specializes on making hard questions appear easy. Uncomplicated positions are more attractive to funding organizations and a news media that can be worked to generate more funds. A constitutional thinker who appears regularly on Nightline makes a better impression on state legislators and potential donors than one whose picture appears only on the cover of university press books. Academics concerned with publicity are best off advancing ideas that can be effectively summarized in a seven-second sound bite. Such claims as Aaffirmative action is simple racism@ or Aonly disguised racists oppose affirmative action,@ if promoted effectively, may reap substantial material rewards. Whether such claims promote intelligent public debate is 
of secondary concern to academic entrepreneurs.

The market driven university slackens demand for courses on constitutional theory and related subjects. Entrepreneurial universities are comfortable performing the educational functions once performed by high schools, providing future workers with the minimal skills necessary for most desirable jobs. The most attractive courses in this learning environment are teach such matters as accounting, which seem directly relevant to work after graduation. Courses on constitutionalism survive because undergraduate consumers mistakenly believe classes in constitutional law to be good preparation for law school. Constitutionalism outside of the courts, unless tweaked to suit the interest of would-be lobbyists, does not thrive in the market driven university.

Market driven constitutional theory further diminishes constitutional education by removing credentialed constitutional theorists from the classroom. Universities driven by financial concerns place even less emphasis on teaching undergraduates than universities driven by research concerns. The traditional problem associated with the prominent researcher who cannot teach is exacerbated when universities routinely encourage faculty to buy out their course obligations. Indifference to undergraduates evolves from a slight handicap to a qualification for obtaining academic positions. As research faculty turn away from undergraduate teaching, courses on constitutionalism are taught in increasingly larger classes, and by adjuncts or graduate students. At best, such classes offer watered down versions of the best constitutional thinking. At worst, they serve as a credentialing service for law schools.

Matters are likely to get worse. Budget conscious state legislators and academic administrators will soon realize that if graduate students and adjuncts are expected to teach the 
constitutional law sequence with some frequency, no good reason exists for ever having the sequence taught by a senior professor. This insight promises to yield policies that further reduce the gap between secondary and post-secondary education. The university of the future may have a teaching faculty with salaries, educational attainments, and course loads similar to that of the teaching faculty in public high schools. Only the few constitutional theorists can obtain research grants will enjoy substantial salaries and the time to do serious constitutional research. They, of course, will not teach undergraduates.

\section{Whither the University}

Constitutional theorists during the eighteenth century celebrated the separation of powers as a practice necessary to maintain republican government. Power united, they believed, would be power abused. AThe concentrat(ion)@ of Aall the powers of government ... in the same hands,@ James Madison and Thomas Jefferson agreed, Ais precisely the definition of despotic government.@ ${ }^{13}$ Contemporary political thinkers insist this insight be applied to power outside of government as well as power within government. Robert Dahl and Michael Walzer champion Acumulative inequalities@ ${ }^{14}$ and Aspheres of justice@ ${ }^{15}$ as means for preventing any resource

${ }^{13}$ Alexander Hamilton, James Madison, and John Jay, The Federalist Papers (New American Library: New York, 1961), pp. 310-11.

${ }^{14}$ Robert Alan Dahl, Who Governs? Democracy and Power in an American City (Yale University Press: New Haven, Connecticut, 1961), p.

${ }^{15}$ Michael Walzer, The Spheres of Justice: A Defense of Pluralism and Equality (Basic Books: New York, 1983). 
from enabling possessors to control all dimensions of human life. Republican government, they recognize, functions best when no person, no institution and no one good dominates. Academic freedom and integrity are aspects of this republican commitment to social pluralism. The optimistic justification of the separation between the academy and the market is that persons trained in constitutional theory will make better judgments than business entrepreneurs on questions of constitutional scholarship. The pessimistic justification is that persons trained in constitutional theory will at least make different judgments than business entrepreneurs.

Resisting the market will be difficult. Peaceful changes in constitutional systems must typically be approved by politicians who gained their positions successfully playing by existing rules. ${ }^{16}$ The steps necessary to maintain and restore traditional academic values will similarly have to be initiated by the intellectual and administrative entrepreneurs who are prospering in the market university. Their practices will more likely increase celebrity constitutional theory, reduce undergraduate exposure to constitutional analysis outside of constitutional law, and sharply limit any thinking about political regimes that seriously attempts social criticism. Academics did not distinguish themselves resisting McCarthy. The question remains whether we will do better resisting Mammon.

${ }^{16}$ See Stephen Skowronek, Building a New American State: The Expansion of National Administrative Capacities (Cambridge University Press: New York, 1982). 